\title{
Effect of intra-articular injection of radioactive colloids of erbium and yttrium on the growth of rabbit legs
}

\author{
C. REBUT-BONNETON*, J. C. ROUCAYROL†, AND F. DELBARRE* \\ From Institut de Rhumatologie, Centre de Recherche sur les Maladies Osteoarticulaires, INSERM*, \\ and ERACNRS 337 Service d'Exploration Functionnelle par les Radioisotopes, $\dagger$ Hôpital Cochin, Paris
}

\begin{abstract}
Rebut-Bonneton, C., Roucayrol, J. C., and Delbarre, F. (1975). Annals of the Rheumatic Diseases, 34, 529-533. Effect of intra-articular injection of radioactive colloids of erbium and yttrium on the growth of rabbit legs. The effect of the intra-articular injection of radioactive erbium 169 and yttrium 90 on the growth of the leg in rabbits has been studied. In colloid state these isotopes are used clinically for synovial ablation. These $\beta$ emitters slow down bone growth in proportion to the amount of radioactivity injected. If the joint has previously been damaged by an inflammatory arthritis the effect of the radiation on the bone growth is reduced.
\end{abstract}

The intra-articular injection of $\beta$ emitters in a colloidal form produces ablation of the synovium. This therapy, which aims at necrosing inflamed synovial membranes, is generally used in adults while in children the injection of an aqueous solution of osmic acid is sometimes preferred (Delbarre, Roucayrol, Menkes, and Ingrand, 1972; Verhaeghe, Delcambre, Thery, Leonardelli, and Bouscati, 1972). However, Menkes, Piatier-Piketty, Zucman, and Delbarre (1972) have shown that injecting osmic acid into the joints of young rabbits caused inhibition of growth, mainly of the femur. Rubin, Casarett, and Farber (1972) have investigated the effects of intra-articular radioactive gold injections in the rat and showed that it damaged articular cartilage. The purpose of the present study was to examine the effects of $\beta$ radiation from erbium $169\left({ }^{169} \mathrm{Er}\right)$ and yttrium 90 $\left({ }^{90} \mathrm{Y}\right)$ on the growth of normal and arthritic rabbit legs.

\section{Materials and methods}

\section{OPERATIVE TECHNIQUE}

Two stainless steel pins were implanted on either side of the knee joints, one through the femur, the other through the tibia. Bone growth was measured by repeated $x$-rays taken for 2 months after injection of the colloid into one joint, while the other limb was used as a control. The distance between the femoral pin and the distal end of the femur enabled the growth of the femur to be measured, likewise the distance between the tibial pin and the tibial plateau indicated tibial growth.
Table I Summary of experiments on the effects of intra-articular radioactive colloids on bone growth

\begin{tabular}{|c|c|c|c|}
\hline \multirow{2}{*}{ Element } & \multirow{2}{*}{$\begin{array}{l}\text { Activity or } \\
\text { volume }\end{array}$} & \multicolumn{2}{|l|}{ Rabbits } \\
\hline & & Normal & Arthritic \\
\hline Colloidal ${ }^{169} \mathrm{Er}$ & $\begin{array}{l}200 \mu \mathrm{Ci} \\
500 \mu \mathrm{Ci} \\
1 \mathrm{mCi}\end{array}$ & $\begin{array}{l}5 \\
5 \\
7\end{array}$ & $\overline{6}$ \\
\hline $\begin{array}{l}\text { Colloidal nonradio- } \\
\text { active Er }\end{array}$ & $0.5 \mathrm{ml}$ & 3 & - \\
\hline Colloidal ${ }^{90} \mathrm{Y}$ & $\begin{array}{l}200 \mu \mathrm{Ci} \\
500 \mu \mathrm{Ci} \\
1 \mathrm{mCi}\end{array}$ & $\begin{array}{l}5 \\
5 \\
5\end{array}$ & $\frac{-}{5}$ \\
\hline $\begin{array}{l}\text { Colloidal nonradio- } \\
\text { active yttrium }\end{array}$ & $0.5 \mathrm{ml}$ & 3 & - \\
\hline
\end{tabular}

Erbium and yttrium were injected in the form of colloid citrate at $\mathrm{pH} 7$, stabilized with gelatine. Chemically these elements are closely related but the disintegration of their radioisotopes is different. ${ }^{169} \mathrm{Er}$ produces $0.340 \mathrm{MeV} \beta$ radiation with a half-life of 9.7 days; ${ }^{90} \mathrm{Y}$ produces 2.2 $\mathrm{MeV} \beta$ radiation with a half-life of 90 hours.

The different amounts of radioactive colloid injected and the number of rabbits in each group are shown in Table I. The volume of colloid was constant $(0.5 \mathrm{ml})$ and nonradioactive colloid was also injected into some animals as a control. Arthritis was induced by injecting $0.1 \mathrm{ml}$ Freund's complete adjuvant into each knee joint 1 week before injection of the radioactive colloid into one joint, the opposite joint being a control. 
Table II Growth of the leg treated with ${ }^{169}$ Er expressed as a percentage of growth in normal controls after 8 weeks

\begin{tabular}{|c|c|c|c|c|c|c|c|c|c|c|}
\hline \multirow{2}{*}{$\begin{array}{l}\text { Material } \\
\text { injected }\end{array}$} & \multirow{2}{*}{$\begin{array}{l}\text { Bone } \\
\text { growth }\end{array}$} & \multicolumn{7}{|c|}{ Rabbit no. } & \multirow[t]{2}{*}{$M e a n \pm S D$} & \multirow[t]{2}{*}{ Significance } \\
\hline & & 1 & 2 & 3 & 4 & 5 & 6 & 7 & & \\
\hline $\begin{array}{l}\text { Nonradioactive } \\
\text { colloidal Er }\end{array}$ & $\begin{array}{l}\text { Femur } \\
\text { Tibia } \\
\text { F \& T }\end{array}$ & $\begin{array}{l}100 \\
100 \\
100\end{array}$ & $\begin{array}{l}95 \\
108 \\
100\end{array}$ & $\begin{array}{l}108 \\
100 \\
105\end{array}$ & & & & & $\begin{array}{l}101 \pm 10 \\
102 \cdot 5 \pm 10 \\
101 \cdot 4 \pm 3\end{array}$ & \\
\hline $200 \mu \mathrm{Ci}{ }^{169} \mathrm{Er}$ & $\begin{array}{l}\text { Femur } \\
\text { Tibia } \\
\text { F \& T }\end{array}$ & $\begin{array}{l}89 \\
119 \\
104\end{array}$ & $\begin{array}{l}108 \\
100 \\
106\end{array}$ & $\begin{array}{l}100 \\
91 \\
91 \cdot 5\end{array}$ & $\begin{array}{l}71 \cdot 5 \\
106 \\
88 \cdot 5\end{array}$ & $\begin{array}{l}81 \\
100 \\
90\end{array}$ & & & $\begin{array}{l}90 \pm 15 \\
103 \pm 11 \\
96 \cdot 8 \pm 11\end{array}$ & NS \\
\hline $500 \mu \mathrm{Ci}{ }^{169} \mathrm{Er}$ & $\begin{array}{l}\text { Femur } \\
\text { Tibia } \\
\text { F \& T }\end{array}$ & $\begin{array}{l}86 \\
118 \\
102\end{array}$ & $\begin{array}{l}73 \\
92 \\
82\end{array}$ & $\begin{array}{l}70 \\
78 \\
74\end{array}$ & $\begin{array}{l}95 \\
100 \\
97\end{array}$ & $\begin{array}{l}81 \\
95 \cdot 8 \\
88\end{array}$ & & & $\begin{array}{l}81 \pm 11.5 \\
96 \cdot 7 \pm 14 \\
88 \cdot 6 \pm 11\end{array}$ & $\begin{array}{l}P=0.05 \\
N S \\
\text { NS }\end{array}$ \\
\hline $1 \mathrm{mCi}^{169} \mathrm{Er}$ & $\begin{array}{l}\text { Femur } \\
\text { Tibia } \\
\text { F \& T }\end{array}$ & $\begin{array}{l}81 \\
86 \cdot 5 \\
83 \cdot 7\end{array}$ & $\begin{array}{l}94 \cdot 5 \\
100 \\
97 \cdot 5\end{array}$ & $\begin{array}{l}73 \\
107 \\
96\end{array}$ & $\begin{array}{l}73 \\
120 \\
96\end{array}$ & $\begin{array}{l}95 \\
100 \\
102 \cdot 5\end{array}$ & $\begin{array}{l}87 \cdot 5 \\
95 \\
91\end{array}$ & $\begin{array}{l}76 \\
100 \\
88\end{array}$ & $\begin{array}{l}83 \pm 10 \\
103 \pm 10 \\
92 \cdot 5 \pm 6\end{array}$ & $\begin{array}{l}P=0.05 \\
N S \\
N S\end{array}$ \\
\hline
\end{tabular}

Table III Growth of the leg treated with ${ }^{90} Y$ expressed as a percentage of normal controls

\begin{tabular}{|c|c|c|c|c|c|c|c|c|c|}
\hline \multirow{2}{*}{$\begin{array}{l}\text { Material } \\
\text { injected }\end{array}$} & \multirow{2}{*}{$\begin{array}{l}\text { Bone } \\
\text { growth }\end{array}$} & \multicolumn{6}{|c|}{ Rabbit no. } & \multirow[t]{2}{*}{$M e a n \pm S D$} & \multirow[t]{2}{*}{ Significanc } \\
\hline & & 1 & 2 & 3 & 4 & 5 & 6 & & \\
\hline Inactive colloid & $\begin{array}{l}\text { Femur } \\
\text { Tibia } \\
\text { F \& T }\end{array}$ & $\begin{array}{l}105 \\
110 \\
108\end{array}$ & $\begin{array}{l}94 \\
94 \\
94\end{array}$ & $\begin{array}{l}94 \\
100 \\
95\end{array}$ & 二 & 二 & & $\begin{array}{l}97 \cdot 3 \pm 6 \\
101 \pm 10 \\
98 \pm 8\end{array}$ & \\
\hline $200 \mu \mathrm{CI}{ }^{90} \mathrm{Y}$ & $\begin{array}{l}\text { Femur } \\
\text { Tibia } \\
\text { F \& T }\end{array}$ & $\begin{array}{l}94 \\
95 \\
94 \cdot 5\end{array}$ & $\begin{array}{l}94 \\
91 \\
92 \cdot 5\end{array}$ & $\begin{array}{l}95 \\
96 \\
95 \cdot 5\end{array}$ & $\begin{array}{l}94 \\
105 \\
100\end{array}$ & $\begin{array}{l}89 \\
100 \\
95\end{array}$ & & $\begin{array}{l}93 \pm 3 \\
97 \cdot 5 \pm 6 \\
95 \cdot 5 \pm 3\end{array}$ & NS \\
\hline $500 \mu \mathrm{CI}{ }^{90} \mathrm{Y}$ & $\begin{array}{l}\text { Femur } \\
\text { Tibia } \\
\text { F \& T }\end{array}$ & $\begin{array}{l}80 \\
79 \\
80\end{array}$ & $\begin{array}{l}81 \\
98 \cdot 5 \\
85\end{array}$ & $\begin{array}{l}80 \\
80 \\
80\end{array}$ & $\begin{array}{l}79 \\
90 \\
85\end{array}$ & $\begin{array}{l}76 \\
96 \\
85\end{array}$ & & $\begin{array}{l}79 \pm 2 \cdot 4 \\
88 \cdot 5 \pm 10 \\
82 \cdot 5 \pm 3\end{array}$ & $\begin{array}{l}P=0.01 \\
N S\end{array}$ \\
\hline $1 \mathrm{mCI}{ }^{90} \mathrm{Y}$ & $\begin{array}{l}\text { Femur } \\
\text { Tibia } \\
\text { F \& T }\end{array}$ & $\begin{array}{l}\overline{55 \cdot 5} \\
85 \cdot 5 \\
69\end{array}$ & $\begin{array}{l}70 \\
78 \\
74\end{array}$ & $\begin{array}{l}\overline{55 \cdot 5} \\
87 \cdot 5 \\
71\end{array}$ & $\begin{array}{l}\overline{82 \cdot 5} \\
94 \cdot 5 \\
89\end{array}$ & $\begin{array}{l}58 \\
90 \\
72 \cdot 5\end{array}$ & & $\begin{array}{l}64 \pm 10 \\
88 \pm 7 \cdot 5 \\
75 \pm 10\end{array}$ & $\begin{array}{l}0.01 \\
0.05 \\
0.05\end{array}$ \\
\hline
\end{tabular}

Table IV Growth of the treated leg as a percentage of the growth of the control leg. Comparison of arthritic and normal rabbits after 8 weeks (the change in growth of radioactive colloids in arthritic joint is expressed as a percentage of growth in control arthritic leg)

\begin{tabular}{|c|c|c|c|c|c|c|c|c|c|}
\hline \multirow[t]{2}{*}{ Colloid } & \multirow[t]{2}{*}{ Animal } & \multicolumn{6}{|c|}{ Rabbit no. } & \multirow[t]{2}{*}{$M e a n \pm S D$} & \multirow[t]{2}{*}{ Significance } \\
\hline & & 1 & 2 & 3 & 4 & 5 & 6 & & \\
\hline${ }^{169} \mathrm{Er} 500 \mu \mathrm{Ci}$ & $\begin{array}{l}\text { Normal } \\
\text { Arthritic }\end{array}$ & $\begin{array}{l}86 \\
92 \cdot 5\end{array}$ & $\begin{array}{l}73 \\
107\end{array}$ & $\begin{array}{l}70 \\
100\end{array}$ & $\begin{array}{l}95 \\
95 \cdot 5\end{array}$ & $\begin{array}{l}81 \\
100\end{array}$ & $\overline{94} \cdot 5$ & $\begin{array}{l}81 \pm 11 \cdot 5 \\
96 \cdot 5 \pm 6\end{array}$ & $P=0.01$ \\
\hline${ }^{90} \mathrm{Y} 1 \mathrm{mCi}$ & $\begin{array}{l}\text { Normal } \\
\text { Arthritic }\end{array}$ & $\begin{array}{l}55 \cdot 5 \\
81 \cdot 5\end{array}$ & $\begin{array}{l}70 \\
85\end{array}$ & $\begin{array}{l}55 \cdot 5 \\
100\end{array}$ & $\begin{array}{l}82 \cdot 5 \\
86\end{array}$ & $\begin{array}{l}58 \\
80\end{array}$ & - & $\begin{array}{l}64 \pm 12 \\
86 \pm 8\end{array}$ & $P=0.01$ \\
\hline
\end{tabular}

* Significance test leg. 


\section{Results}

Three effects of the irradiation of the joints were considered: the total increase in bone length during the 2 months after injection of the colloids, fluctuations of growth during this period, and changes in the $x$-ray appearances. The overall effects of the intraarticular radioactive colloids on bone growth in healthy rabbits is shown in Tables II and III. The change in growth is expressed as a percentage of growth in the control leg. Nonradioactive colloid did not cause any alteration of growth; the radioactive colloids inhibited growth when they were at or above a particular level of radioactivity. After injection of $200 \mu \mathrm{Ci}{ }^{169} \mathrm{Er}$ the growth of the femur was $90 \pm 15 \%$ of the control and not significantly different from the control femur; on the other hand, $500 \mu \mathrm{Ci}$ and $1 \mathrm{mCi}$ caused a significant reduction of growth, being $81 \pm 11.5$ and $83 \pm 8 \%$, respectively, of the control. There was no inhibition of growth of the tibia even after injection of a much higher dose of radioactivity.

$500 \mu \mathrm{Ci}$ of ${ }^{90} \mathrm{Y}$ produced a significant inhibition of growth of the femur. This was more evident when $1 \mathrm{mCi}$ injected into the knee joint resulted in decreased

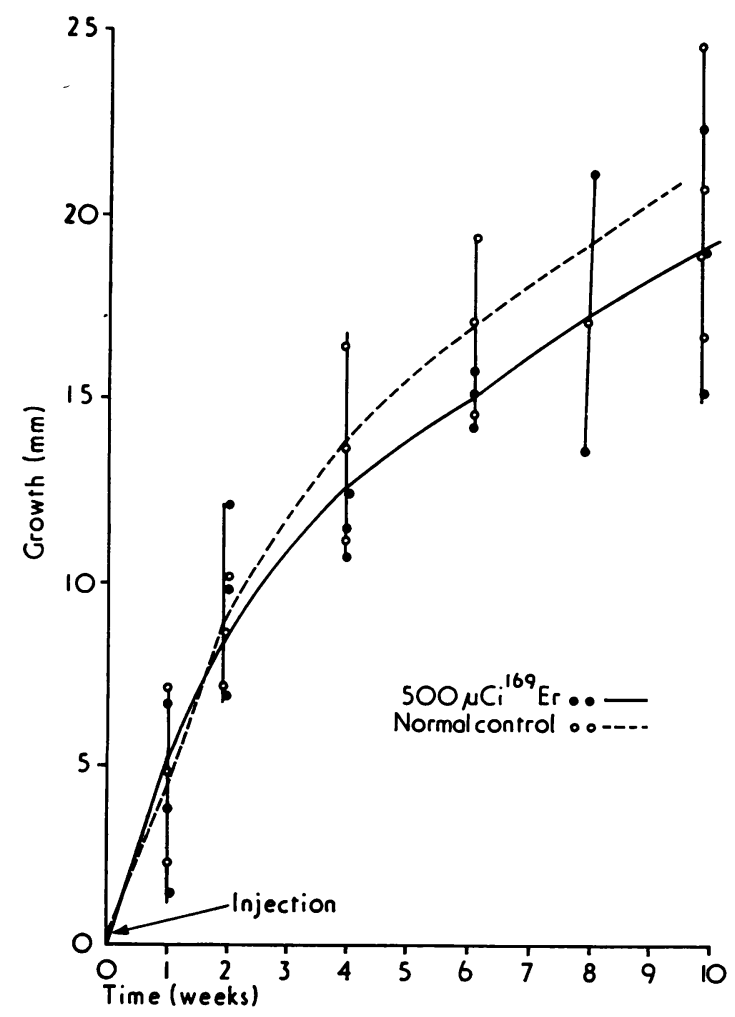

FIG. 1 Growth curves of control femur and femur after injection of $500 \mu \mathrm{Ci}{ }^{169} \mathrm{Er}$ into the knee joint of a normal rabbit

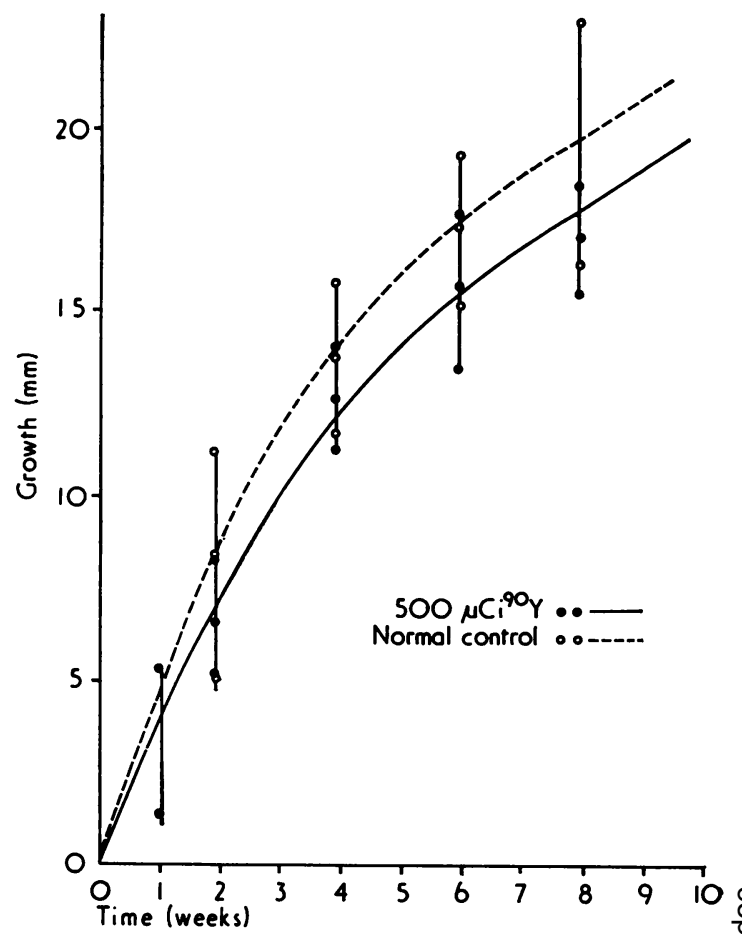

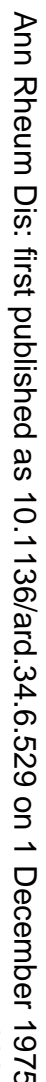

FIG. 2 Growth curves of control femur and femur after injection of $500 \mu \mathrm{Ci}{ }^{90}$ Yinto the knee joint of a normal rabbit

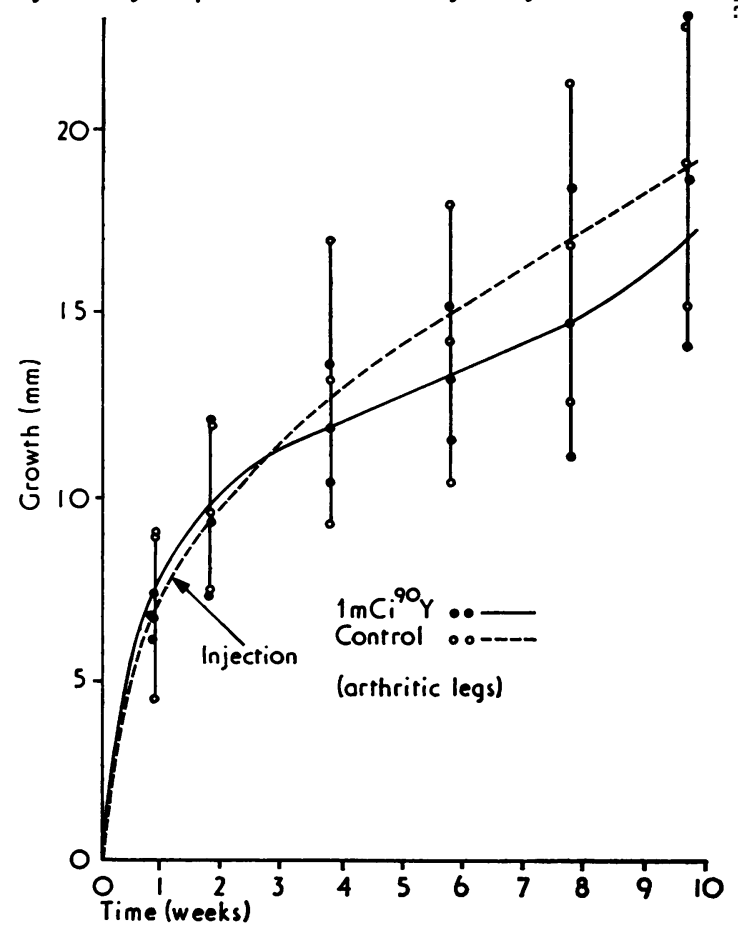

Fig. 3 Growth curve of control femur and femur after injection of $1 \mathrm{mCi}{ }^{90} \mathrm{Y}$ into the knee joint of an arthritic rabbit 
growth of the femur to $64 \pm 12 \%$ of the control and of the tibia to $88 \pm 7.5 \%$ of the control.

Table IV shows the results in healthy rabbits and rabbits with an induced arthritis. After injection of $500 \mu \mathrm{Ci}{ }^{169} \mathrm{Er}$ into the knee of healthy rabbits the growth of the femur was $81 \pm 11.5 \%$ of the control femur; in arthritic rabbits it was $96.5 \pm 6 \%$ of the control. These two results are significantly different. Hence, the presence of arthritis prevents the effects of intra-articular ${ }^{169} \mathrm{Er}$ on bone growth.

After injection of $1 \mathrm{mCi}$ colloidal ${ }^{90} \mathrm{Y}$, the femur in the injected limb grew $64 \pm 12 \%$ of the control femur, while in arthritic rabbits it was $86 \pm 8 \%$ of the control. These differences are also highly significant. However, a residual untoward effect remained as there was significant inhibition in growth of the limb of arthritic rabbits compared to that of normal controls.

Fig. 1 shows the growth curves of the normal femur, and after injection of $500 \mu \mathrm{Ci}$ colloidal ${ }^{169} \mathrm{Er}$ into the knee joint. Fig. 2 shows the effects of $500 \mu \mathrm{Ci}$ colloidal ${ }^{90} \mathrm{Y}$ in healthy rabbits. The effects of ${ }^{169} \mathrm{Er}$ on bone growth is delayed for 2 weeks. On the other hand, ${ }^{90} \mathrm{Y}$ begins to inhibit bone growth immediately it is injected into the joint. Representative growth curves showing the protective effect of an arthritis are shown in Fig. 3. It can be seen that both limbs grow at the same rate for 1 month after injecting ${ }^{90} \mathrm{Y}$ into an arthritic knee joint. Radiological intraarticular opacities were present, their extent being related to the dose of radioactivity injected.

At autopsy it was shown that these opacities corresponded to yellowish granulations grouped or dispersed in the synovial tissue. Microscopically, the granulations were visible in necrotic zones loaded with calcium (stained with haemalun) around which foreign body reactions had developed. They were specially noticeable after ${ }^{90} \mathrm{Y}$ injections, but were more discrete after ${ }^{169} \mathrm{Er}$, but were always present. By superimposing the tibae in $x$-rays of the normal knee joint of control rabbits and those of the opposite knee, it could be shown that the knee which had been injected had developed a flexion deformity of up to $40^{\circ}$ (in rabbits given $1 \mathrm{mCi}{ }^{90} \mathrm{Y}$ ). This flexion was present in all animals given $1 \mathrm{mCi}$ and in one animal out of two injected with $500 \mu \mathrm{Ci}$. This deformity provides evidence of an abnormal growth of the femur.

In some animals it was possible to see a deformity of the distal end of the femur, particularly in rabbits given $1 \mathrm{mCi}^{90} \mathrm{Y}$, the bony lesions showing as an irregularity of the bone contour. $X$-rays of the joints of untreated arthritic rabbits showed that alteration of the curvature of the head of the femur can accompany the flexion deformity. Oedema of the periarticular tissues was also apparent. The flexion deformity was not improved 2 months after injection of radioactive ${ }^{169} \mathrm{Er}$ or ${ }^{90} \mathrm{Y}$.

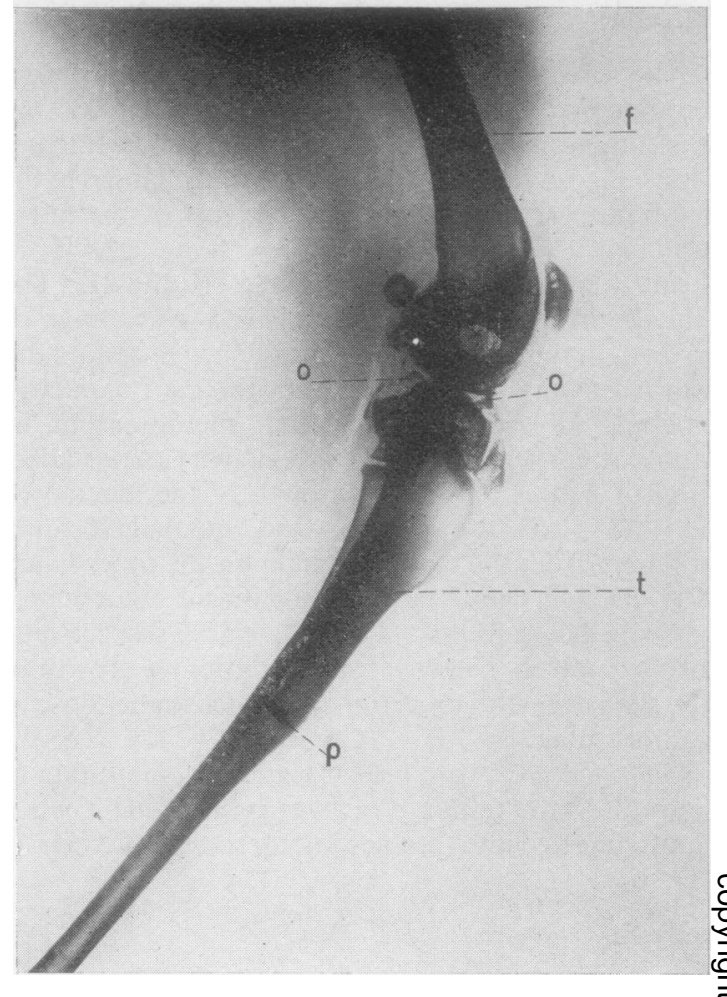

FIG. 4 X-ray of the hind limb of a rabbit injected with $500 \mu$ Ci colloidal ${ }^{90} Y$ into its knee joint. Note the position of the pin ( $p$ ) and the intra-articular opacities (o). $f=$ femur; $t=$ tibia

\section{Discussion}

These experiments have shown the inhibitory effect of $\beta$ radiation on bone growth. The energy of the radiation is not the only factor; the half-life of the radioisotope is equally important, as both ${ }^{169} \mathrm{Er}$ and ${ }^{90} \mathrm{Y}$ damage growing bone. It is probably the total dose of radiation and not the dose rate that is the important factor.

The absorption in depth of $\beta$ radiation from ${ }^{169} \mathrm{Er}$ is extremely rapid. The effect of ${ }^{169} \mathrm{Er}$ can only be explained by the shape of the joint cavity, the growth cartilage of the femur in the joint cavity being in direct contact with the radioisotope; this does not happen with the tibia, and could explain its decreased radiosensitivity of the femur.

${ }^{90} \mathrm{Y}$, whose $\beta$ radiation penetrates further than ${ }^{169} \mathrm{Er}$, produces a greater and more regular effect on bone growth, and may also affect the growth of the tibia. When arthritis is present the radioisotope is dispersed over the hyperplastic synovial villi and its action is less marked upon the bone.

We acknowledge with thanks the excellent assistance of Ms. Françoise Gaisne. 


\section{References}

Delbarre, F., Roucayrol, J. C., Menkes, C. J., AND Ingrand, J. (1972) In 'Les Synovior thèses', volume 1, p. 171 FDP, Paris

Menkes, C. J., Piatier-Piketty, D., Zukman, J., AND Delbarre, F. (1972) Rev. Rhum. 39, 513 (Injections articulaires d'acide osmique chez le lapin; répercussion sur la croissance)

Rubin, P., CASARETT, G., AND FARBER, P. (1972) Radiology 103, 685 (The effect of intra-articular- ${ }^{198}$ Au instillation on articular cartilage)

Verhaeghe, A., Delcambre, B., Thery, J. N., Leonardelli, J., AND Bouscati, F. (1972) Thérapie, 48, 35 (Interet des synoviorteses par injection intra-articulaire d'acide osmique dans la polyarthrite rhumatoide) 